\title{
Application of Mental Health Scale and Perceived Stress in Elderly Assisted by Basic Health Units
}

\begin{abstract}
Anna Cláudia Freire de Araújo Patrício1, Brenda Feitosa Lopes Rodrigues², Milenna Azevedo Minhaqui Ferreira2 ${ }^{2}$, Ruth Alves Gomes2 ${ }^{2}$ Thays Domingos de Brito², Ana Rebeca Soares de Medeiros ${ }^{2}$, lana Virgínia Bezerra Félix ${ }^{2}$, Jiovana de Souza Santos ${ }^{3}$
\end{abstract}

\section{Abstract}

Objective: Parse through the mental health scale and perceived stress in elderly assisted by basic health units.

Method: This is an exploratory study, quantitative, and performed in the period from March to July 2015, in the municipality of João Pessoa/Paraíba in northeastern Brazil, where reach selected 67 elderly persons aged 60 years or more, out of a total of 200 elderly linked to family health strategy and with preserved cognitive capacity.

Results: Showed that the majority of the elderly did not submit mental suffering reported low level of perceived stress.

Conclusion: We can see that elderly inserted into family and social coexistence have lower level of stress. Among the many disorders that affect the elderly, such as the limitation on motor coordination, difficulty of locomotion and metabolic deficits, mental health needs special attention.

\section{Keywords}

Mental Health; Elderly Health Centers.
1 Nurse. Master in nursing by Universidade Federal da Paraíba. Member of the study group and research in aging and social representations/GIEPERS. João Pessoa/ Paraíba, Brazil.

2 Graduate in nursing at Centro Universitário de João Pessoa UNIPE. Member of the study group and research in aging and social representations/GEPERS. João Pessoa/ Paraíba, Brazil.

3 Nurse. Member of the study group and research in aging and social representations/GIEPERS. Universidade Federal da Paraíba. João Pessoa/ Paraíba, Brazil.

\section{Contact information:}

\section{Anna Cláudia Freire de Araújo} Patrício.

Address: Av. Monteiro da Franca, 1480. João Pessoa/Paraíba, Brazil.

\section{झ claudia.freirearaujo@gmail.com}

\section{Introduction}

Social changes, economic, political and technological come significantly contributing to the increased longevity of the population. Preliminary data from the Brazilian Institute of geography and statistics (IBGE) of 2010 show that life expectancy in the country has 
increased about three years between 1999 and 2009. The new Brazilian life expectancy is 73.1 years. Among women are registered the lowest mortality rates that represent $55.8 \%$ of persons over the age of 60 years. Female life expectancy rose from 73.9 to 77 years, while men of 66.3 reached 69.4 years [1].

One of the common health problems in old age, are mental disorders that affect about one-third of the elderly population. There are few epidemiological studies of General psychiatric morbidity in the elderly in our midst, $26.4 \%$ prevalence of pointing to $33.6 \%$ in Brazilian urban communities [2].

The term "stress" was defined as a set of specific and General reactions of the organism in the face of persistent stimulation of aversive nature, able to change the homeostatic balance, accompanied by predictable changes biochemical, psychological, cognitive and behavioral change related to a fact or stressful event [3].

The symptoms of stress stimulate the body to react negatively, each agent stressor responds differently in relation to the affected person. The elderly experience significant changes such as illness and loss of physical ability being regarded as the main cause for stress in old age [4].

Healthy aging involves in addition to other factors, the preservation of organic systems, conducting daily life activities, engaging in physical activity, proper nutrition, good metal performance and minimal stress. Such phenomena improve quality of life, the performance of the elderly and reduce the biopsychosocial probability of disease [5].

Therefore, this study aims to analyze through mental health scale and perceived stress in elderly assisted by basic health units.

\section{Methodology}

This is an exploratory study, transversal and quantitative. Carried out in the period from March to July 2015, in a basic unit of family health in the city of João Pessoa/Paraíba, South zone. Were selected for the study 67 elderly persons aged 60 years or more, out of a total of 200 elderly linked to family health Strategy and with preserved cognitive capacity. Deleted all the old people not linked to the family health strategy, bedridden with aphasia, severe mental conditions. This sample was calculated in the program Statdisk version 11.1.0 USES with 10\% margin of error and 95\% confidence level.

Important to consider that in this study were considered elderly, as the status of the elderly that is regulated by law 10,741/2003, those aged over 60 years, justifying the inclusion criterion [6].

Data collection using the stress scale Perceived, being requested that the elderly would indicate that often felt or thought a certain way, during the last month in relation to the concern, disability, nervousness, confidence, control, irritability. Response options ranged from 0 (never) to 4 (very often), and to the questions four, six, seven and eight as follows: $0=4 ; 1=3 ; 2=2 ; 3=1 ; 4=0$. The scale scores established of 0 to 40 . From the analysis and scores, the classification for the stress level was as follows: 0-10 without stress, stress take 11-20, 21-30 moderate stress and high stress 31-40 [7].

For mental health assessment scale was validated in Brazil, determined by the Perceived Mental Questionnaire (SRQ-20), recommended by the Ministry of health [8]. The results of this scale bring subsidies that make it possible to better guide the planning of interventions focused on health of the elderly, with emphasis on healthy living habits, pain and problems that may have bothered you in the last 30 days, as frequency of headache, lack of appetite, hand tremors, poor digestion, difficulty in thinking clearly and idea of ending life.

The SRQ-20 has 20 items for tracking of mental disorders non-psychotic. The answers are Yes/ No. Each affirmative answer scores with the value 1 to make the final score through the sum of these values. The scores obtained are related to the likelihood of the presence of disorder non-psychotic, 
ranging from 0 (no odds) to 20 (extreme probability). When the result of the sum of responses achieve equal or greater value to 7 , indicates mental distress [8].

The data were processed in the program Statistical Package for the Social Sciences (SPSS) version 19.0, through descriptive statistics and inferential statistics with Pearson test to verify the correlation between quantitative variables: perceived stress and age, mental health and age. The test of Pearson was considered strong with value between 0.7 and 1 . It was considered a significance level of $5 \%$.

The study was approved by the ethics and Research Committee of the Centro Universitário de João Pessoa - UNIPÊ, CAEE/ZIP CODE: 38840214.7.0000.5176. all participants were asked to sign the informed consent (TFCC), in accordance with resolution 466/2012 National Health Council that governs the survey among humans [9].

\section{Results}

The elderly studied had an average age of 68.9 years and standard deviation of 6.6 , and $71.6 \%$ (48) women. As for the civil State, 58.2\% (39) married, $23.9 \%$ (16) widows, $11.9 \%$ (8) singles and $6 \%$ (4) divorced. Schooling pointed $7.5 \%$ (5) illiterate, 58.2\% (39) literate, 6\% (4) full primary school, $23.9 \%$ (16) high school and any elderly person said have higher education.
The assessment of mental distress for likely to develop non-psychotic disorder obtained 7.1 average and standard deviation 4.1, with maximum and minimum 160 , being categorized as shown in table 1.

The Pearson correlation coefficient for age and mental distress proved to be weak with 0.29 value.

The application of the perceived stress scale, showed average of 17.5 and standard deviation score 4.48, high score 31 and 9 minimums. The elderly was classified as the stress level, as shown in table 2.

For the items that comprise the perceived stress scale include the results in table 3 .

Table 1. Mental distress for elderly linked to Basic Health Unit. João Pessoa/PB. N = 67.

\begin{tabular}{|l|c|c|}
\hline \multicolumn{1}{|c|}{ Classification } & N & $\%$ \\
\hline Without mental distress & 38 & 57 \\
\hline With mental distress Score greater than 7 & 29 & 43 \\
\hline Total & 67 & $100 \%$ \\
\hline Source: survey data, 2015. N = number of subjects. \% = percentage.
\end{tabular}

Table 2. Stress level in elderly linked to Basic Health Unit. João Pessoa/PB. $\mathrm{N}=67$.

Table 3. Representation of responses for each item in the scale of Perceived Stress in elderly linked to Basic Health Unit. João Pessoa/PB. N = 67 .

\section{Items} Almost Never

N

19

28.4

you been worried about because of something that happened unexpectedly?

In the past month, how often did you feel unable to control the important things in your life?

In the past month, how often did you feel nervous and under stress?

19 24 35.8 20 29.9 17.9

\begin{tabular}{|l|c|c|}
\hline \multicolumn{1}{|c|}{ Variables } & N & $\%$ \\
\hline No stress & 1 & 1.5 \\
\hline Light Stress & 49 & 73 \\
\hline Moderate Stress & 16 & 24 \\
\hline High Stress & 1 & 1.5 \\
\hline Total & 67 & $100 \%$ \\
\hline \multicolumn{2}{|c|}{ Source: survey data, 2015. N = number of subjects. \% = percentage. } \\
\hline
\end{tabular}

Source: survey data, 2015. $\mathrm{N}=$ number of subjects. $\%=$ percentage.

Never

\begin{tabular}{c|c} 
Some times \\
N & $\%$
\end{tabular}

\begin{tabular}{|c|c|}
\hline \multicolumn{2}{|c|}{ Often } \\
\hline $\mathrm{N}$ & $\%$ \\
\hline
\end{tabular}

Very often N

$\%$




\section{Items}

Never

Almost Never

Some times

\section{Often}

Very often

N

$\%$

N

$\%$

N

$\%$

In the past month, how often did you feel confidence in your ability to deal with their personal problems?

5

7.5

10.4

7

16.4

11

43.3

29

22.4

15

In the past month, how often did you feel that things were going your way?

In the past month, how often he felt he couldn't abide with all the stuff you had to do?

In the past month, how often was able to control his irritation?

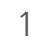

17.9

14

20.9

15

22.4

22

32.8

13

19.4

3

4.5

12

In the past month, how often did you feel to have everything under control?

In the past month, how often did you feel mad for things beyond your control?

22

\begin{tabular}{|l|l|l|l|}
\hline 32.8 & 21 & 31.3 & 10 \\
\hline
\end{tabular}

In the past month, how often felt that the difficulties were accumulating so much he couldn't overcome?

\begin{tabular}{|l|l|l|l|l|l|l|l|l|}
\hline 17.9 & 10 & 14.9 & 14 & 20.9 & 19 & 28.4 & 12 & 17.9 \\
\hline
\end{tabular}

10.4

12

17.9

13

19.4

20

29.9

15

23

34.3

21
20

22.4

20

\section{Source: survey data, 2015. $\mathrm{N}=$ number of subjects. $\%=$ percentage}

To verify the correlation between the age of the elderly and the perceived stress scale score, there was association between variables with Pearson equal to 1 , revealing statistical linear dependence between the variables.

The Pearson correlation coefficient resulted in 1 between mental health variables and perceived stress, with statistical significance $p=0.01$.

\section{Discussion}

Table 1 shows that the majority of the elderly did not submit mental suffering. Among the many disorders that affect the elderly, mental health deserves special attention. Upon reaching the third age, individuals can present psychiatric frames are common in this age group. Such mental losses generaIly include dementia, depression or psychotic States [10]. Mental disorders impair 20\% of the elderly population, among which stand out the dementia and depression as prevalent [11]. In the study the emotional balance can be justified by the improvement in the quality of life, health services, public policy, education, intended for this population. Seniors who attend a USF, family health unit has less likely to develop mental distress due to the various services offered.

Table 2 points out that most elderly presents stress takes, being compatible to the 64 elderly registered at UBS of Minas Gerais (2000) [12]. The numerous everyday changes arising from cognitive changes, other than those of physical, mental or social origin, experienced by the elderly result in threat to its maintenance, thus constituting, biopsychosocial stressor capable of triggering somatoform autonomic and Behavioral responses in an attempt to reestablish the homeostatic imbalance. It is known that stress is due to the numerous changes in the aging process, when not identified at an early stage may affect the quality of life of the elderly, affecting your health.

Stress can be classified as an organic response to different stimuli, culminating in emotional arousal and characteristic symptoms. The reaction will be the set of phenomena mobilized by the body [5]. 
Depression is the most common mental disorder that arises in the final stages of life, reaching approximately $10.3 \%$ of the elderly population in the world. Is closely linked to health problems, disability, mortality and suicide. Countries like United States, Britain, Japan and Malaysia have reported an increase in the prevalence of depression in the elderly. In addition, depression has shown that it is the cause of an increase in the use of medical services, therefore, of greater weight on health services in several countries [13].

In this context, focuses on public policies can be better established. And, for those related to population aging, the aspect of effectiveness must absolutely involve different sectors, such as health, the economy, the labour market, social security and education. This demonstrates the full commitment necessary for the elderly [4].

It is evidenced by table 3, that most of the elderly this study shows low level of perceived stress. Studies in Arcos de Valdavez/Portugal, demonstrated that elderly living at home have lower level of stress than elderly residing in long-stay Institutions-ILP, fact that related to social support, being an impact damper element, namely, the perception that others are available to provide emotional comfort or practical assistance the need seems to be particularly beneficial to health and well-being. Moreover, women tend to evaluate situations of life with greater intensity than men. Elderly single/divorced, and in widowhood present higher levels of stress, which corroborates with the present study where the civil State is composed mostly by elderly married $58.2 \%$ [14].

In accordance with what has been observed, studies carried out on Paraiba (2013), note that seniors who don't live alone have better quality of life, because they seem to have greater emotional support and sense of security arising from a sense of belonging and integration [15]. Sense of life as a moderating variable stress helps people to stand up against us. Seniors who invest more time in ac- tivities that involve family and friends if they realize with more control, are emotionally more stable and creative [4].

Older adults exposed to new situations, unpredictable, in which components of your self-identity, for example, autonomy and intellectuality, can be negatively evaluated. As well as biological, cognitive-functional modifications, emotional, social and economic, arising from the aging may reflect in high stress symptoms [16].

The Association of physical activity with healthy aging presents a serious relationship, especially when it comes to the benefits related to physical, psychological and social factors. The activity contributes not only to the improvement of the physical condition of the elderly, but also reflects on the self-esteem, body image, quality of life, depression, stress, well-being and life satisfaction [17].

Studies conducted in Colombia realize that much of the population has manifested symptoms suggestive of poor mental health, by questions of, exposure to situations of social vulnerability, lack of access to social and health services and low perception of their quality of life. Sociodemographic factors such as level of education, women, widows, elderly people with low social support, unfavorable economic situation, age and area of residence, are related to the prevalence of mental distress. People who don't have a social network of support given by friends, family, or in some cases, institutional support, have worse mental health and depression. Social inequalities reflected in the condition described in the literature as "paradox of inequality", where higher-risk groups share similar social characteristics [18].

One of the limitations of the study, there is the low number of elderly investigated and analyzed variables that can justify the level of stress and mental suffering, such as: education, physical activity, medication use, quality of life, work. Therefore, suggest studies on stress and mental health in the elderly, as indicators of significant points that include 
healthy practices, making it possible to change the lifestyle, able to promote autonomy and improve self-esteem. In this way, nursing needs to wake up to the development of elderly health strategies, developing systematization of nursing care considering the reality of this population.

Study in Minas Gerais (2013) shows that stress can be understood and respected in accordance with the environment in which the individual is inserted, this fact suggests greater understanding of the quality of the aging process in which study subjects are involved [19].

\section{Conclusion}

This study made it possible to analyze how often the elderly linked to Basic Health Unit felt or thought a certain way, during the last month in relation to the concern, disability, nervousness, confidence, control, irritability; through the Perceived Stress scale, being highlighted in higher percentage without mental distress. Was also a prevalence of mild stress.

The stress is due to the numerous changes in the aging process. When not identified at an early stage may affect the quality of life of older people doing it to increasingly isolate of society by not feeling able to interact and to be understood. It should be noted that the senior citizen is less likely to suffer from diseases resulting from stress when included in the family get-together.

To ensure that the elderly have their freedom and independence is fundamental to the health team understands the complexity that involves the process of aging. It is important for the nurse to investigate the quality of life of the elderly, the factors that contribute to the emergence of stress, to draw a careful strategy to prevent possible complications and promote the rehabilitation of the affected.

\section{References}

1. Brasil. Instituto Brasileiro de Geografia e Estatística (IBGE). Censo Demográfico 2010. [Acesso em 13 out 2015]. Disponível em: http://www.ibge.gov.br/censo2010/index.php

2. Clemente AS, Loyola Filho Al, Firmo JOA. Concepções sobre transtornos mentais e seu tratamento entre idosos atendidos em um serviço público de saúde mental. Cad saúde pública. 2011; 27(3): 555-64. Disponível em: http://www.scielo.br/scielo. php?script=sci arttext \&pid=S0102311X2011000300015

3. Borges CS, Luiz AMG, Domingos NAM. Intervenção- cognitivocomportamental em estresse e dor crônica [Internet]. 2009 out/dez; Arq. Ciênc saúde. 2009; 16(4):181-6. Disponível em: http://repositorio-racs.famerp.br/racs ol/vol-16-4/v16-4.htm

4. Melo RLP, Eulálio MC, Gouveia VV, Silva HDM. O efeito do estresse na qualidade de vida de idosos: o papel moderador do sentido de vida. Psicol. Reflex Crit. 2013; 26 (2):222-30. Disponível em: http://www.scielo.br/scielo.php?script=sci artte xt\&pid=S010279722013000200002

5. Carvalho JCR, Andrade EF, Valim-Rogatto PC, Rogatto GP. Estresse em idosos participantes de um programa de atividades físicas. Rev. digital Buenos Aires. 2014; 1(188). Disponível em: http://www.efdeportes.com/efd188/estresse-em-participantesde-atividades-fisicas.htm

6. Brasil. Presidência da República. Dispõe sobre o Estatuto do Idoso e dá outras providências. Casa Civil. Subchefia para Assuntos Jurídicos. Brasília. 2003. Disponível em: http://www. planalto.gov.br/ccivil_03/leis/2003/L10.741.htm

7. Luft CDB, Sanches SO, Mazo GZ, Andrade A. Versão brasileira da escala de estresse percebido: tradução e validação para idosos. Rev. saúde pública. 2007; 41(4): 606-15. Disponível em: http://www.scielo.br/scielo.php?script=sci artte xt\&pid=S003489102007000400015

8. World Health Organization Expert Committee on Mental Health. Organization of mental health services in developing countries: sixteenth report of the WHO Expert Committee on Mental Health. Geneva: World Health Organization; 1975.

9. Brasil. Ministério da Saúde (BR). Resolução n 466, de 12 de dezembro de 2012. Dispõe sobre Pesquisas com Seres Humanos. Diário Oficial da União. Brasília, 2012.

10. Gordilho A, Sérgio J, Silvestre J, Ramos LR, Freire MPA, Espindola $E$, et al. Desafios a serem enfrentados no terceiro milênio pelo setor saúde na atenção integral ao idoso. Rio de Janeiro: UnATI/ UERJ; 2000. Disponível em: http://www.crde-unati.uerj.br/ publicacoes/textos_Unati/unati1.pdf

11. Garbaccio JL, Silva AG, Barbosa MM. Avaliação do índice de estresse em idosos residentes em domicílio. Rev. RENE. 2014; 15(2):308-15. Disponível em: http://www.revistarene.ufc.br/ revista/index.php/revista/article/view/1660 
12. Morillo LS. Fatores moduladores do estresse em idosos. [Dissertação] São Paulo: Faculdade de Medicina da USP; 2000.

13. Jinhui L, Yin-Leng T, Schubert F. Depression and Psychosocial Risk Factors among Community-Dwelling Older Adults in Singapore. J Cross Cult Gerontol [Internet]. 2015; DOI 10.1007/ s10823-015-9272-y.

14. Barbosa T, Lobo F. Suporte Social e Stress em idosos residentes no meio rural: estudo comparativo entre idosos institucionalizados e idosos a viver no domicílio. Aletheia. Associação Científica e Cultural. Centro Regional de Praga; 2013. Disponível em: http://repositorio.ucp.pt/bitstream/10400.14/17038/1/artigo6.pdf

15. Borim F S A Barros M B A, Botega N J. Transtorno mental comum na população idosa: pesquisa de base populacional no Município de Campinas, São Paulo, Brasil. Cad saúde pública. 2013; 29(7):1415-26. Disponível em: http://www.scielo.br/ scielo.php?pid=S0102311X2013000700015\&script=sci arttext

16. Talarico JNS, Caramelli PNR, Chaves EC. Sintomas de estresse e estratégias de coping em idosos saudáveis. Rev. Esc. Enferm. USP [Internet]. 2009;43(4): 803-09. Disponível em: http://www.scielo. br/scielo.php?pid=S0080-62342009000400010\&script=sci $\underline{\text { arttext }}$

17. Rocha SV, Almeida MMG, Araújo TM, Virtuoso Júnior JS. Atividade física no lazer e transtornos mentais comuns entre idosos residentes em um município do nordeste do Brasil. J. Bras. Psiquiat. [Internet]. 2011; 60(2): 80-5. Disponível em: http://www.scielo.br/scielo.php?pid=\$0047208520110002000 02\&script=sci arttext

18. Agudelo-Suárez Andrés A, Posada-López Adriana, MenesesGómez Edwin J. Salud mental en adultos mayores atendidos en la red hospitalaria pública de Medellín, Colombia. Rev Peru Med Exp. Salud Publica [Internet]. 2015 Dec. [Cited 2016 Feb. 05] ; 32(4): 701-708. Available from: http://www. scielosp.org/scielo. php? script=sci arttext\&pid=S172646342015000400011\&lng=en

19. Vicente NG, Ferreira LA, Rezende MP. Percepção do estresse ocupacional por bombeiros militares de uma cidade do interior de Minas Gerais. Rev. Pesqui Cuid. Fundam. (Online). 2013; 5(3):75-84. Disponível em: file:///C:/Users/Anna\%20 Cl\%C3\%A1udia/Downloads/2116-15053-1-PB\%20(2).pdf
Publish in International Archives of Medicine

International Archives of Medicine is an open access journal publishing articles encompassing all aspects of medical science and clinical practice. IAM is considered a megajournal with independent sections on all areas of medicine. IAM is a really international journal with authors and board members from all around the world. The journal is widely indexed and classified Q1 in category Medicine. 